Section Editors

David C. Spencer, MD

Steven Karceski, MD

Daniel Kantor, MD

\title{
The impact of migraine on school performance
}

WHAT QUESTION DID THE RESEARCHERS IN THIS STUDY ASK? The researchers in this study tackle an often overlooked problem: how migraine headache affects the school performance of children. ${ }^{1}$ It is bad enough to have migraines as an adult (it may mean missing work, family functions, or social time), but migraines, which often begin in childhood, can have a negative impact on the developing brain during school years. Many studies have shown that doing well in middle and elementary school results in better high school and college performance. Higher education opens up opportunities for a better income and financial quality of life. If migraines make schoolwork harder and lead to worse grades, this can affect future opportunities and brain development. The researchers set out to describe the scope of this problem.

WHAT IS A MIGRAINE? WHAT MAKES IT DIFFERENT FROM OTHER HEADACHES? Migraines are a type of primary headache disorder, meaning that they are not generally thought to be caused by something else, like a growth in the brain. Migraines cause headaches that are usually on one side of the head. Sometimes the side may change or the pain may be on both sides at the same time. They are usually moderate to severe in intensity, last for longer than 4 hours if not treated, get worse with activity, and throb or pulsate (although more rarely they have a dull or more stabbing feeling). Aside from the actual head pain, migraine are often accompanied by nausea or difficulty with light and loud noises.

Some people have warning signs (often sparkling lights or other visual symptoms) for migraines, called "auras." These are called "classic migraines." More often there is no aura, and these are called "common migraines."

WHAT DID THE STUDY SHOW? The authors wanted to find out more about how migraines affect school performance, so they approached two important sources of information: teachers and parents. The authors asked the parents about any history of headaches and they asked the teachers about the child's school performance. The authors found that about a quarter of children had headaches with features of migraines and that there were even children who had headaches on most days of the month (this is called chronic migraine). There was a connection between coming from a poorer home and the chances of having migraines. Children with migraine missed more days of school due to the headaches than children with other types of headache disorders (not migraines).

There were a number of factors that led to poor school performance:

- Having migraines at all vs not having migraines

- More frequent migraines

- Longer migraines

- More intense/severe migraines

- Having associated nausea with the migraines

- Coming from a poorer home

Some factors did not affect school performance:

- Age (all the children were 5-12 years of age)

- Sex

- Race

WHERE AND HOW WAS THIS STUDY SET UP? Instead of looking at a single city or school, the authors studied children across different regions in Brazil.

I'M FROM THE UNITED STATES; WHAT DOES THIS STUDY HAVE TO DO WITH ME AND MY CHILDREN? Studies of populations in different parts of the world help us to understand more about what goes on with our youth and in our schools. A similar study in your hometown may likely show similar results. Of course the results may be a little different in terms of percentages, but children have developing human brains regardless of their address; remember, human beings are more similar than we are different.

WHAT'S THE TAKE AWAY MESSAGE FROM THIS STUDY? Migraines during childhood can have a negative effect on school performance. If your child has headaches, it is important to get a clear diagnosis. Primary care providers often diagnose and manage headaches. Neurologists are experts who often have specialized training in the diagnosis and treatment of migraines. If your child is diagnosed with migraines, your doctor can recommend ways for your child to avoid or prevent headaches and also provide effective treatments for the headaches that do occur. Although this study did not look at this specifically, there is reason to believe that actively treating the migraines may help your child to do better in school. 
Section Editors

David C. Spencer, MD

Steven Karceski, MD

\section{About migraine}

Previously published: Klein E, Spencer D. About migraine. Neurology 2009;73:e42-e43.

WHAT IS MIGRAINE? A migraine headache is usually a severe, throbbing headache that is typically on one side of the head and may last for hours. It is 3 times more common in women than men. ${ }^{2}$ Often migraine headaches are accompanied by nausea and sometimes vomiting. Generally, when someone is experiencing a migraine, he or she will feel the need to lie down in a dark, quiet place until the headache ends. The cause of migraine is not well understood, but it is believed that abnormal brain or nerve activity causes blood vessels in the brain to both dilate and constrict, leading to the headache. Some migraines begin with what is called an aura. Auras usually consist of strange visions of light or color. Occasionally an aura may also involve a familiar smell or taste or weakness or numbness on one side of the body. After the aura, the migraine headache begins.

HOW COMMON IS MIGRAINE? An estimated 28 million Americans experience migraines. Specifically, that is $17 \%$ of American women and $6 \%$ of American men. ${ }^{3}$ Headache is the most common reason why patients see a neurologist, and migraine is the most common type of headache that neurologists see.

WHAT CAUSES A MIGRAINE? The cause of migraine is not well understood, but it is believed that blood vessels in the brain both dilate and constrict, leading to the headache. During an aura, brain cells become overexcited, and this increase in brain activity leads to blood vessel changes, which cause the headache. Sometimes the migraine disorder is hered- itary, passed down through families. Often triggers such as stress, temperature changes, hormonal changes, or changes in diet cause a migraine to start.

WHAT ARE THE TREATMENTS FOR MIGRAINE? Many different medication treatments are available for migraines. Some work to stop migraines after they start. Others are taken every day to prevent future migraines. Migraine treatments have varying side effects. Depending on a patient's migraine frequency and severity and other medical conditions, doctors may recommend different migraine medications. Certain types of mental health counseling aimed at reducing stress levels to control headaches may also help reduce migraines.

\section{FOR MORE INFORMATION}

AAN Patients and Caregivers site

http://patients.aan.com/go/home

Migraine Research Foundation

http://www.migraineresearchfoundation.org

American Headache Society Committee for Headache Education (ACHE)

http://www.achenet.org

National Headache Foundation

http://www.headaches.org

\section{REFERENCES}

1. Arruda MA, Bigal ME. Migraine and migraine subtypes in preadolescent children: association with school performance. Neurology 2012;79:1881-1888.

2. Stewart WF, Lipton RB, Celentano DD, Reed ML. Prevalence of migraine headache in the United States. JAMA 1992;267:64-69.

3. Lipton RB, Scher AI, Kolodner K, Liberman J, Steiner TJ, Stewart WF. Migraine in the United States: epidemiology and patterns of health care use. Neurology 2002;58:885894. 


\section{Neurology}

\section{The impact of migraine on school performance \\ Daniel Kantor}

Neurology 2012;79; e168-e169

DOI 10.1212/WNL.0b013e3182745a97

This information is current as of October 29, 2012

\section{Updated Information \& Services}

References

Subspecialty Collections

Permissions \& Licensing

\section{Reprints}

including high resolution figures, can be found at: http://n.neurology.org/content/79/18/e168.full

This article cites 3 articles, 2 of which you can access for free at: http://n.neurology.org/content/79/18/e168.full\#ref-list-1

This article, along with others on similar topics, appears in the following collection(s):

All Headache

http://n.neurology.org/cgi/collection/all_headache

Migraine

http://n.neurology.org/cgi/collection/migraine

Pediatric headache

http://n.neurology.org/cgi/collection/pediatric_headache

Information about reproducing this article in parts (figures,tables) or in its entirety can be found online at:

http://www.neurology.org/about/about_the_journal\#permissions

Information about ordering reprints can be found online:

http://n.neurology.org/subscribers/advertise

Neurology ${ }^{\circledR}$ is the official journal of the American Academy of Neurology. Published continuously since 1951, it is now a weekly with 48 issues per year. Copyright Copyright (? 2012 by AAN Enterprises, Inc.. All rights reserved. Print ISSN: 0028-3878. Online ISSN: 1526-632X.

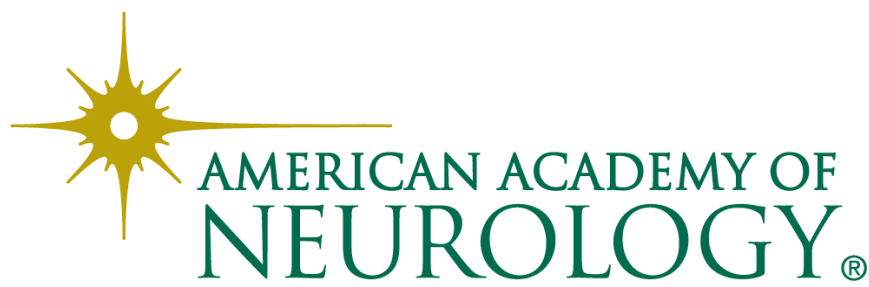

